\title{
Employment in Nineteenth Century Indian Textiles*
}

\author{
Michael J. TwOMEY \\ University of Michigan, Dearborn
}

The "de-industrialization" of India has been a topic of extensive debate in the literature of political economy. Officials of the East India Company warned against it in the early days of the 18 th century. ${ }^{1}$ That the growth of the Lancashire cotton mills came at the expense of Indian handicraft production has been widely accepted, especially among certain nationalist economic historians, led by Dutt (1956). ${ }^{2}$ A focal point in the recent academic discussion has becn Morris's (1963) article, reprinted, along with comments from other scholars, in the March 1968 issue of the Indian Economic and Social History Review, and in Morris et al. (1969), in which he declared "there is a strong likelihood that the traditional sector, generally speaking, did not decline absolutely in economic significance and therefore did not constitute a depressing element in the performance of the nineteenth century economy. It is even possible that absolute growth occurred." 3 Among other comments, critics pointed to the weak statistical basis of Morris's position. One important study he did cite is the Thorner (1962) analysis of the Indian census data of 1881 and 1931,

* The author thanks members of the UM-Ann Arbor Economic History Seminar, D. A. Farnie, Don Anderson, and Richard Roehl, for comments on earlier drafts.

' See Dutt (1956), Chap. XIV. Humanitarian considerations were probably less important to them than was the protection of their own near monopoly in the trade of Indian piece goods.

2 A good presentation of the different subcurrents of the nationalist position is Ganguli (1977). As another example. Maddison (1971, p. 54) comments "There is a good deal of truth to the de-industrialization argument." Baran (1957, p. 149) states, "(Britain's) commercial policy destroyed the Indian artisan and created the infamous slums of the Indian cities ... Its economic policy broke down whatever beginnings there were of an indigenous industrial development. . . ." It might be noted that Baran's treatment of the "Roots of Backwardness" of India gives more emphasis to the "drain" of resources from India than to de-industrialization per se. As noted by Morris (1963) and Chaudhuri (1968), that is another thorny issue of Indian economic history.

${ }^{3}$ Morris (1963, p. 613). Immediately above this quotation, another phrase refers specifically to handloom weavers. We shall return to this distinction at the end of the paper. There are many other stimulating hypotheses in Morris's paper which we shall not consider here. 
which indicated no increase in the percentage of the population dependent on agriculture. ${ }^{4}$ Surveys of 19 th century Indian economic history by Chaudhuri (1968), Kumar (1972), and most recently Robb (1981) have emphasized the still unsettled empirical basis of this discussion.

This paper shall attempt to attach rough orders of magnitude to the different variables important in determining the accuracy of Morris's statement. ${ }^{5}$ The first step in this exercise is the collection and presentation of data on Indian trade-exports and imports, of both yarn and clothwhich is generally possible from 1790 on. The more difficult task is the construction of time series for total production and consumption; these are presented from $1880 \mathrm{on}$. On the basis of this data we shall distinguish two periods of marked effects on Indian textile employment; an earlier one due the reduction of exports, the second due to the inroads of English textiles on production for local use. Certain average productivity ratios permit the conversion from output changes to employment effects. With regard to Morris's assertion, we shall argue that there was an absolute decline in handicraft textile employment over the century, and highlight the period 1850-1880 as that of strongest displacement of domestic handicrafts by British exports.

The cotton plant was first domesticated in India, whose textile trade is so ancient that Indian cotton fabrics have been found in the tombs of the pharaohs. For the period under consideration, we shall distinguish five stages of Indian textile production and trade: (1), the years prior to 1830 , involving a steady decline in the volume of Indian handmade exports from a high in the 1790s; (2), 1830-1850, when exports stagnated while the growth of imports from Britain was arguably not greater than the growth of domestic demand due to population growth; (3), 1850-1880, which saw accelerating textile imports, as well as the successful foundation of the domestic manufacturing industry; (4) 1880-1913, at the end of which imports peaked; (5) the post-1913 period, when domestic manufacturing dominated both imports and hand weaving.

Textile mills were attempted in India as early as 1818 , but for a variety of reasons the first successful one was established only after 1850. It is well known that these mills did not have the benefits of significant tariff protection, which was only to come in the $1920 \mathrm{~s}^{6}{ }^{6}$ The story of the evolution of the Indian spinning and weaving industries is best told by Mehta (1953, 1954); other important sources are Gadgil (1971), Gandhi (1930), and Govil (1950).

${ }^{4}$ In contrast to Thorner, Bagchi (1976) found a decline in that percentage over the period 1809-1901, for the area of Bihar. Bagchi's use of data has been severely criticized by Vicziany (1979) and Robb (1981). We shall argue below that the period analyzed by Thorner is inappropriately late.

${ }^{5}$ One could quarrel with the implication that the absence of absolute (as opposed to relative) decline is sufficient to avoid being a depressing element.

${ }^{6}$ On Indian tariff policies, see Rider (1970), Harnetty (1972), and Dewey (1978). 
The data on Indian trade, presented in Table 1, form the basis for much of our periodization of the Indian textile experience, which unfortunately excludes considerations of political developments. There is a clear turning point in 1830 , when the subcontinent becomes a net importer of cloth. The mid-century acceleration of imports was halted by the "cotton famine" of the early $1860 \mathrm{~s}$, but growth resumed thereafter. In 1880 she became a net exporter of (machine spun) yarn. Cloth imports fell after 1913, and never regained their prewar level. At the end of the period, yarn exports were being replaced by cloth exports.

Under the East India Company, the export of cotton textiles increased considerably, expanding from an inter-Asian trade toward the European markets, marking its apex at the end of the 18 th century, ${ }^{7}$ when the major part of exports was sent to England for re-export onto the continent and elsewhere. The suggestion of Table 2 is that the re-exported part of Indian shipments to England continued to rise up into the 1790s, while the (relatively smaller) domestic English market was already falling by then due to accelerating home production. By the turn of the century, English goods clearly dominated the world market.

What happened thereafter to total Indian textile exports is difficult to specify with exactitude. Some information is presented in Table 3. In contrast to the collapse of the export market to England in the decades after 1800 , the rest of the Indian exports was not as severely damaged, apparently declining slightly in volume, and by some factor less than half in price. The price change reflects a drop in quality, because English exports first displaced the higher part of the Indian trade, as the price differential between mechanically spun and hand spun yarn increased with the fineness of the yarn. On the basis of the data in Table 4, we would conclude that real cloth prices fell in England after 1800; Parshad (1932, p. 210) cites a report suggesting that Indian piece goods sold in England had reached their highest sale prices in the 1780 s. Table 4 also suggests that the price decreases in England due to mechanization and technical improvements were aided, at least between 1815 and 1845 , by the decline in the price of the raw material, due to the expansion of American supplies. Of course, one cannot necessarily infer price movements in India on the basis of information on English prices, because of transport costs, the English tariffs and other trade impediments, as well as the breaking up of the East India Company's trade monopoly. Combining these considerations and the incomplete data in Tables 3 and

\footnotetext{
${ }^{7}$ The author has not found any data for total Indian cloth exports before 1790, Nevertheless, trade to England expanded considerably. Chaudhuri $(1978$, p. 548) shows average annual exports of 441 thousand pieces in 1756-1760 (down from a high of over one million in 1727). Milburn (1813; p. 234) reports yearly trade of 874 thousand during 1771-1779, and (p. 415) over two million during 1791-1800, after which it declined. An undetermined, but presumed small, part of this growth was due to the displacement of trade in non-British hands. See Arasaratnam (1980) and Chaudhuri (1974).
} 


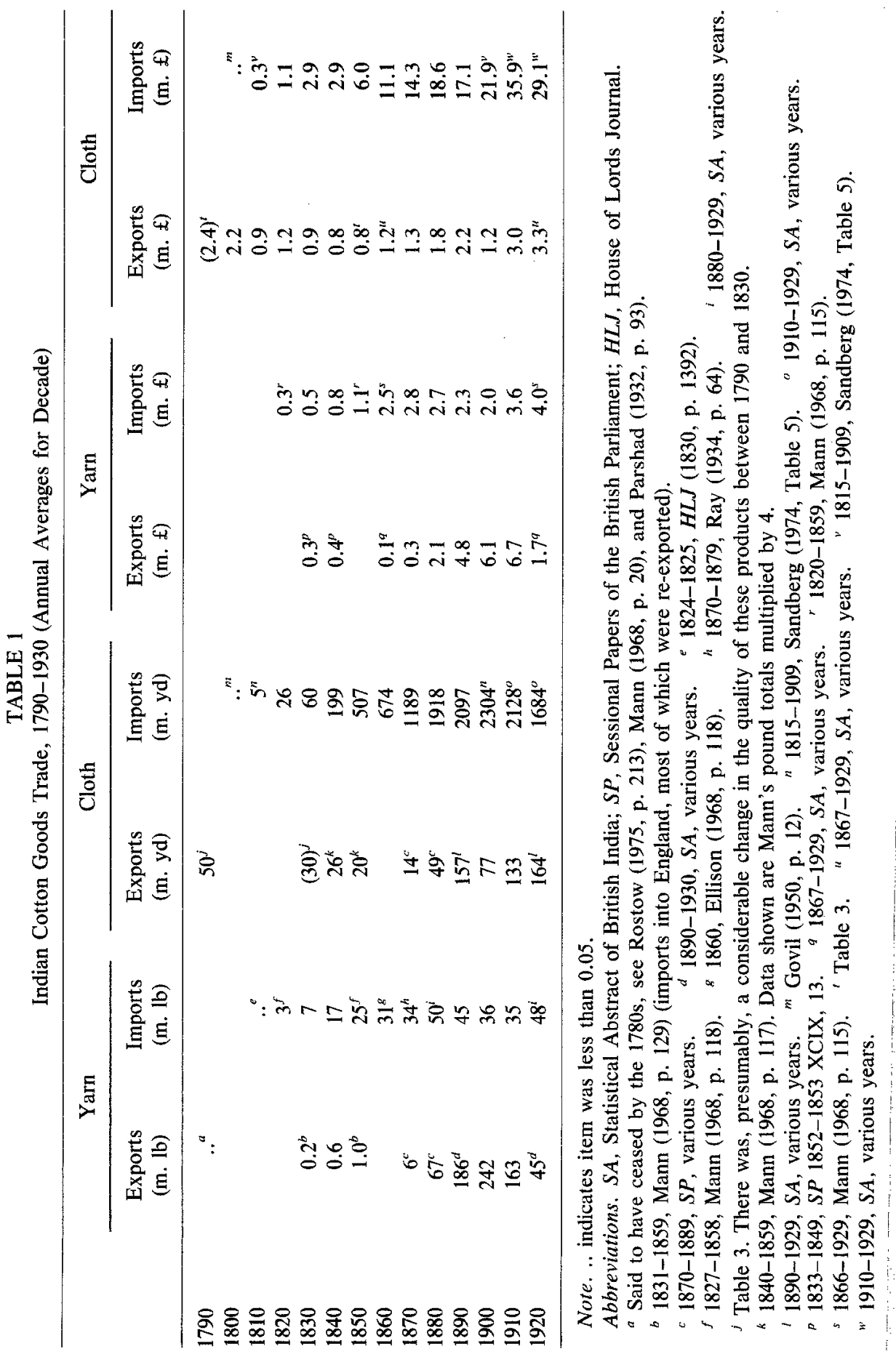


TABLE 2

Production and Trade, $1780-1830$

\begin{tabular}{|c|c|c|c|c|c|c|}
\hline $\begin{array}{l}\text { Decade } \\
\text { beginning }\end{array}$ & $\begin{array}{l}\text { India's total } \\
\text { cloth exports }\end{array}$ & $\begin{array}{l}\text { England's } \\
\text { imports of } \\
\text { textiles } \\
\text { from Asia }\end{array}$ & $\begin{array}{l}\text { England's } \\
\text { re-exports } \\
\text { of Asian } \\
\text { textiles }\end{array}$ & $\begin{array}{l}\quad 4 \\
\text { Implied } \\
\text { English } \\
\text { consumption } \\
\text { Asian } \\
\text { textiles }\end{array}$ & $\begin{array}{l}\text { English } \\
\text { production }\end{array}$ & $\begin{array}{l}\text { English } \\
\text { exports } \\
\text { of } \\
\text { cottons }\end{array}$ \\
\hline 1780 & & 1,344 & 394 & 950 & 5,400 & 766 \\
\hline 1790 & $(2430)$ & 1,687 & 1,142 & 545 & 10,000 & 3,380 \\
\hline 1800 & 2,251 & 827 & 777 & 50 & 18,900 & 15,871 \\
\hline 1810 & 976 & 515 & 432 & 83 & 29,200 & 18,742 \\
\hline 1820 & 1,224 & 363 & 429 & -66 & 33,100 & 16,879 \\
\hline 1830 & 902 & 347 & 406 & -59 & 45,600 & 22,398 \\
\hline
\end{tabular}

Note. All data in thousand $£$. Data may refer to subperiods of indicated decades.

Sources. Column 1 from Table 3. Columns 2 and 3 from the Appendixes of Davis (1979). Column $4=$ column $2-$ column 3. Columns 5 and 6 from Deane and Cole (1967). It is clear from Table 3 that columns $2-4$ are predominantly Indian cotton piece goods, as opposed to silk and/or Chinese products.

4, we shall conjecture a reduction by two-thirds of "real" Indian textile exports between 1790 and 1830 . The tentative nature of this estimate is clear, but it shall turn out that it establishes an order of magnitude with sufficient precision for later comparisons.

Our suggested chronology of the Indian experience during the extended 19 th century basically utilizes the period $1830-1850$ to separate the period of declining Indian exports from that of declining handicraft production, which we argue is a post- 1850 phenomenon. This position is based on comparisons of known imports with our own estimates of production in 1850 and the period after 1880 .

The reports of various governmental boards of inquiry present a reliable overview $^{8}$ of the mill industry after 1900 , with limited data reaching back to 1879; we have presented this in Table 5 , along with our estimates of hand spinning. The major gap in our sources is any information about the evolution of hand spinning. What appears to be the most thorough analysis of the subject places the volume of hand spinning of yarn at about 60 million pounds in $1931,{ }^{9}$ while another source indicates that it

${ }^{8}$ There has been considerable discussion on the fine points of the appropriate methodology of constructing these tables, specifically, the conversion factor relating pounds of machine spun yarn to yards of machine woven cloth (Mehta, 1954, Chap. 4). Neither wishing nor qualified to enter this debate, we have chosen to follow the Tariff Board's methodology in constructing the early parts of Table 5 .

${ }^{9}$ Desai $(1953$, p. 77$)$. Gandhi (1930, p. 72) gives similar estimates for that period. 
MICHAEL J. TWOMEY

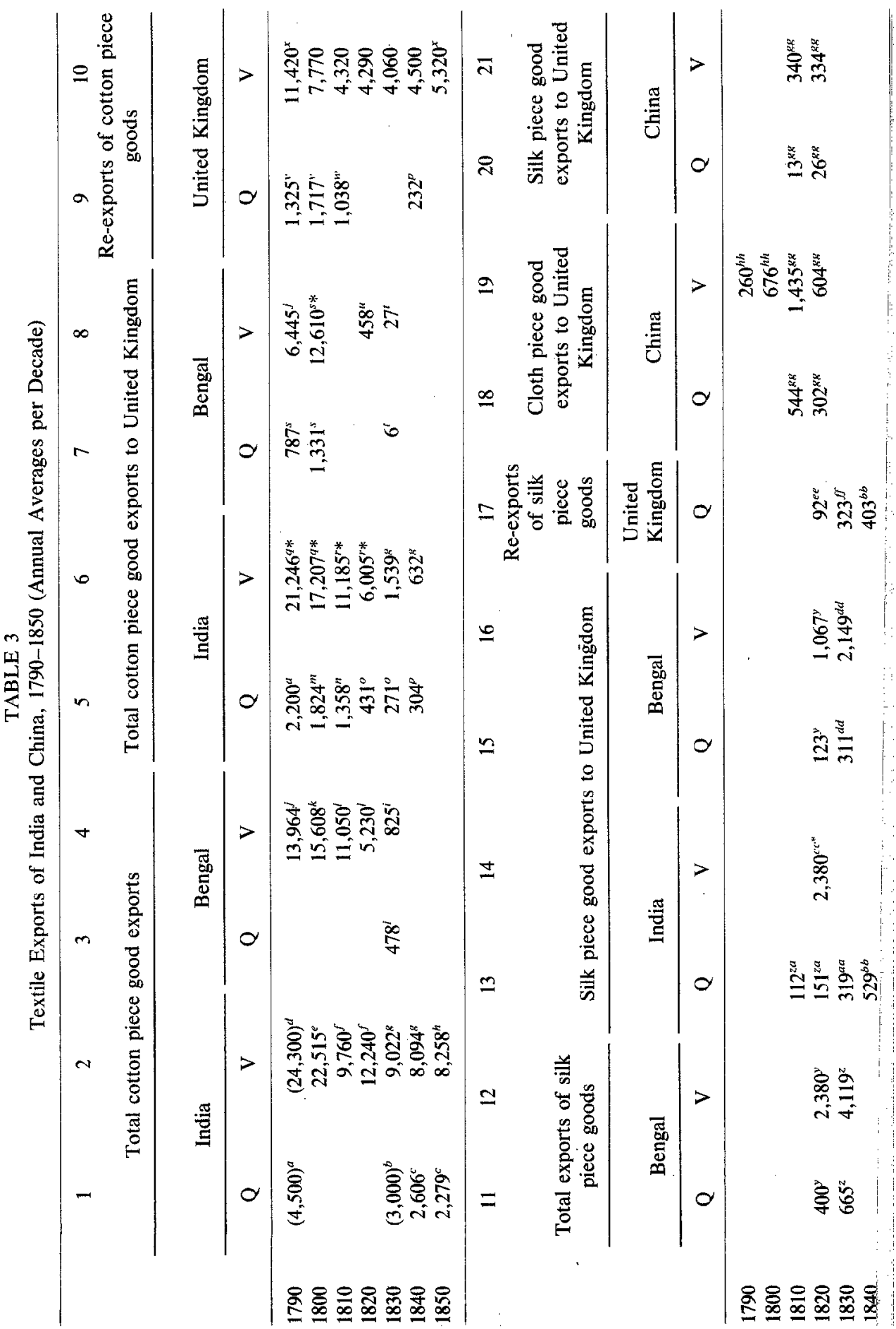




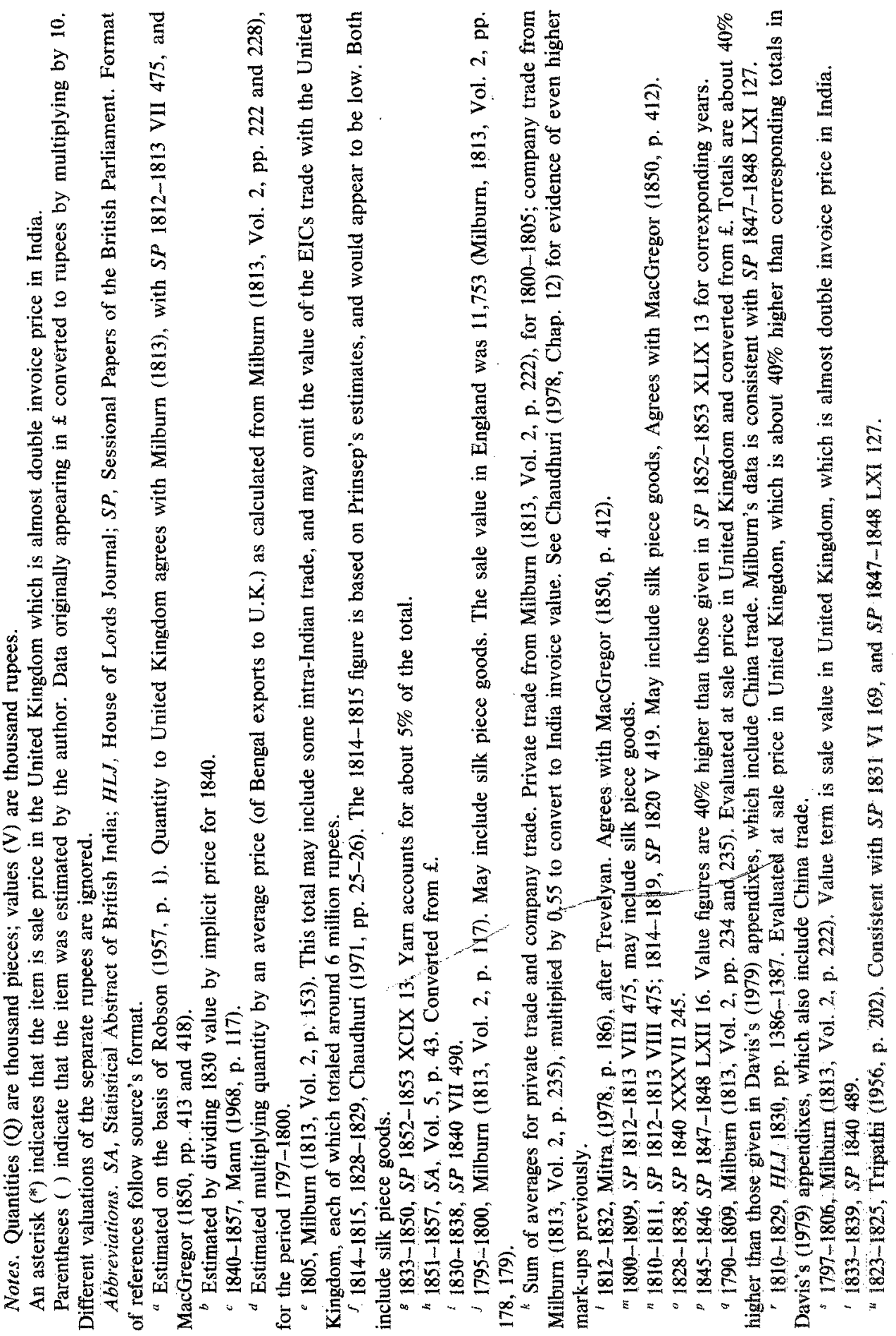




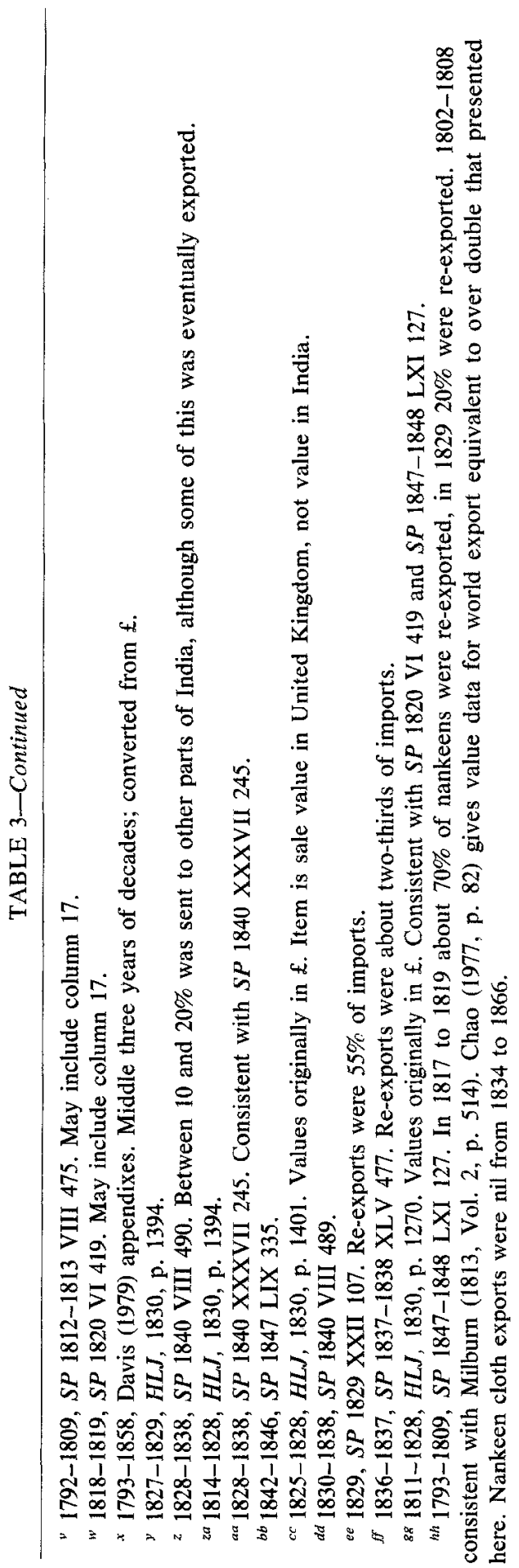


TABLE 4

Price Indices in Britain, 1800-1872 $(1815-1816=100)$

\begin{tabular}{|c|c|c|c|c|c|c|c|c|}
\hline \multirow[b]{2}{*}{ Year } & \multicolumn{2}{|c|}{ General } & \multirow{2}{*}{$\begin{array}{c}\text { Cloth } \\
3\end{array}$} & \multirow{2}{*}{$\begin{array}{c}\text { Yarn } \\
4\end{array}$} & \multirow{2}{*}{$\begin{array}{c}\text { Other } \\
\text { exports } \\
5\end{array}$} & \multirow{2}{*}{$\begin{array}{c}\text { Cotton } \\
6\end{array}$} & \multirow{2}{*}{$\begin{array}{l}\text { Cloth } \\
\div \text { raw } \\
\text { cotton } \\
\quad 7\end{array}$} & \multirow{2}{*}{$\begin{array}{c}\text { Yarn } \\
\div \\
\text { cotton } \\
8\end{array}$} \\
\hline & 1 & 2 & & & & & & \\
\hline 1800 & 131 & 114 & (153) & (108) & & (84) & & 128 \\
\hline $1815-1816$ & 100 & 100 & 100 & 100 & 100 & 100 & 100 & 100 \\
\hline $1828-1830$ & 85 & 72 & 45 & 38 & 60 & 29 & 142 & 126 \\
\hline $1843-1845$ & 73 & 70 & 24 & 29 & 49 & 22 & 101 & \\
\hline $1870-1872$ & & 76 & 24 & 45 & 50 & 40 & 57 & \\
\hline
\end{tabular}

Sources. Column 1 is the Gayer-Rostow index, column 2 is the Rousseau index, both from Deane and Cole (1967). Columns 3-7 are from Imlah (1958, Tables II and IV). The cloth price for 1800 is the ratio of calculated average prices at the EICs sales in London of imported Indian piece goods, from MacGregor (1850, pp. 412, 413, and 418). The rest of column 3 is consistent with Sandberg (1974, pp. 239-240). Column 8 and the first entries in columns 4 and 6 (which refer to 1803-1805) are from MacGregor (1850, pp. 806-807). The average count of the yarn referred to is 25 , which is rather coarse. Utilizing Ellison (1968, p. 55) and MacGregor (1850, p. 807), price indices for " $40 \mathrm{~s}$ " would be 1779,488 ; 1799,$299 ; 1830,37(1815-1816=100)$. Pre-1815 prices for higher count yarns were even higher.

was the equivalent of 25 million pounds in the $1950 \mathrm{~s} .{ }^{10}$ We have inserted in columns 11 and 12 of Table 5 time series on hand spinning, which, although based on very fragmentary evidence, ${ }^{1}$ do allow a more complete vision of the whole Indian textile sector by indicating limits on the relative orders of magnitude of hand spinning inside it. For the early years,

${ }^{10}$ Robson $(1957$, p. 19). It is possible that handicraft spinning had reached its low after 1880 but before 1930 , from which it rebounded due to the economic and political factors mentioned in the text. This possibility would not alter our main conclusions.

"Factors include trends in mill consumption and exports of raw cotton, and the production estimates as reported by the International Institute of Agriculture, together with yield data from Harnetty (1972, p. 94) and Heston (1973), and the regional production estimates of Harnetty (1972, p. 54) and McAlpin (1975, p. 666). One other major consideration is the estimate cited by Mann (1968, p. 64) of Indian consumption of cotton at $2 \frac{1}{2}$ pounds per person. This is comparable to estimates made for other pre-industrial cotton growing societies. For China, see Feuerwerker (1970) and Chao (1977). For Japan, see the production data in Okhawa et al. (1966, p. 178), and imports from Seki (1956, pp. 302-303). Based on these and other sources, the author has estimated production and consumption for the 1870-1930 period for both countries; in 1870, per capita consumption of cotton in China was 3 pounds per year, and 2.6 pounds in Japan. See also Ellison (1968, p. 144). Tables are available on request. In contrast, average English consumption in 1850 was $7 \frac{1}{2} \mathrm{lb}$, up from about $\frac{1}{4} \mathrm{lb}$ in 1773. Compare Deane and Cole (1967, pp. 8, 144, and 145) with Robson (1957, Appendix Table 1).

For the conversion of hand woven textiles, we have followed the Indian Tariff Board (India, 1927), Utley (1931, p. 286), Wadsworth and Mann (1931, p. 120), and Gandhi (1930. p. 85 ) in using 4 yards of cloth per pound of cotton. 
MICHAEL J. TWOMEY

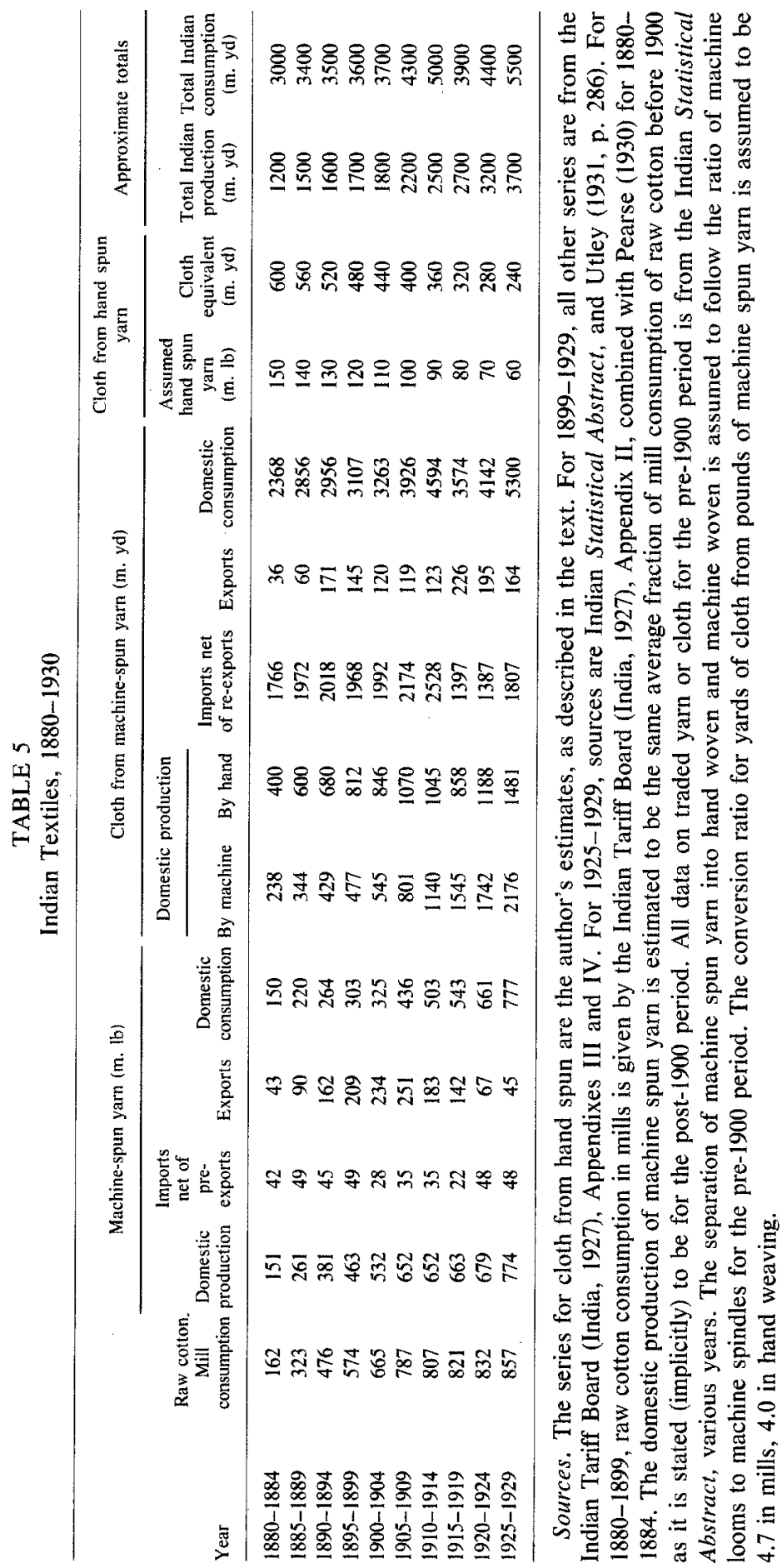


changes of 50 million pounds in our estimate of hand spinning, or by $33 \%$, would alter our total consumption figure by about $7 \%$, and our total production estimate by $16 \%$.

During the period 1880-1914, there was a broadly continuous growth in Indian machine production of cloth. Hand weaving appears to have grown, ${ }^{12}$ in spite of the large decline we assume for hand spinning. Note also that more machine spun yarn was consumed by hand weaving than by machine looms up until the $1910 \mathrm{~s}$, over half a century after the mill industry became established. Furthermore, between 1880 and 1913 the growth of imports was equaled by the growth of mill production of cloth. Cloth imports peaked in 1913, and declined markedly during World War I. They were not able to recover their market after the war for two reasons: the imposition of protective tariffs in India, and the nationalist Swadeshi movement. Factory production of cloth, having surpassed both hand weaving and imports during the war, continued to rise thereafter, and India finally re-established herself as a net exporter of cotton textiles in the 1940s. Our estimates of per capita consumption ${ }^{13}$ are 11 yards in 1880,15 yards in 1913, and 17 yards in 1930. Per capita imports were 1 yard in 1840,7 yards in $1880,{ }^{14} 8$ yards before World War I, and 5 yards

${ }^{12}$ The future of hand weaving continued to be an important issue after World War II; see Mehta (1954, Chap. 4).

${ }^{13}$ All estimates of Indian population in the text are interpolated from McEvedy and Jones (1978), who suggest the following totals: 1800,190 million; 1850, 230 million; 1900 , 290 million; 1925, 330 million. In contrast, Morris (1974) snggested 197, 237, 285, and 315 million, respectively. There has been a tendency to raise the estimated population for 1800 ; Morris et al. earlier $(1969$, p. 149) had cited a "commonly accepted estimate" of 100 to 125 million for 1800 .

"Hunter (1886, p. 600) stated that "it may be roughly estimated that about three fifths of the cotton cloth used is woven in the country from native thread or from imported twist." Farnie (1979, p. 119) cites this passage in his discussion of the mutual importance of the Indian market and British production. Our corresponding estimate is only two-nfths. Hunter's fraction, combined with well-measured import totals and fairly reliable estimates of machine spun yarn, implies a volume of 500 million pounds of hand spun yarn. This would raise the per capita consumption figure to 17 yards of cloth, or over 4 pounds of cotton, which seems too high. Given Hunter's general authority, the discrepancy' is puzzling. As we shall argue below, acceptance of the 17 yards per capita consumption figure for the eariy 1880 s would not invalidate our conclusion that a rise in per capita imports from 1 yard in 1850 to 7 yards in 1880 severely hurt handicraft activities (in the face of a small rise in per capita income), but it would be difficult to explain the implicit vertiginous drop in hand spinning between 1880 and 1930, and a near stagnation of overall consumption in spite of a $25 \%$ increase in population and a $20 \%$ increase in per capita income (according. to both Mukerji and Heston). Unfortunately, reliable statistics on the production of raw. cotton, from which one could deduce handicraft production by subtracting exports and mill consumption, are not available.

We might also note here that the use by Wright (1974) of Indian exports to the United Kingdom as a proxy for total:Indian exports of raw cotton seriously underestimates the latter. In 1880 the United Kingdom only received about one-fifth of total Indian cotton exports, according to the Indian Statistical Abstract. Hanson's (1979) critique of Wright's argument also ignored developments in Asian textile trade. 
in 1930. By 1929, the respective shares of total Indian cloth consumption were Indian mills, $38 \%$, imports $32 \%$, hand weaving using mill yarn, $26 \%$, and hand weaving using hand spun yarn, $4 \%$.

Although it is not a central focus of our paper, a few comments on the factors affecting the growth of industrial production are perhaps appropriate. The opening of the Suez canal lowered external transport costs considerably, while the expansion of railroads lowered internal costs (McAlpin, 1975), increasing the supply of cotton and expanding the domestic market for piece goods. Table 6 supports our conjecture that raw cotton in India was relatively cheaper before the cotton famine, giving effective protection to the fledgling industry. Note also in Table 6 that the relative price of yarn and cloth, compared to the overall price index, fell by almost half between 1873 and 1900 , in spite of a fall of the Indian rupee with respect to the British pound. ${ }^{15}$ Finally, there is a reversal of the trend in the relative prices of cotton and cloth after the start of World War I, which continued after the wartime scarcities were over. This may be a reflection of the postwar tariffs in India.

Earlier we suggested a five-part periodization of the Indian textile experience. We shall now argue that the most severe employment effects of the so-called de-industrialization occurred during the first and third of these stages, with the third having the greatest impact.

In 1790, production for export was not large compared to home consumption in India. Robson (1957) puts total annual exports at 50 million yards during the 1790s; assuming a population of 190 million and consumption at 9 yards per capita ${ }^{16}$ would imply that exports were less than $3 \%$ of total production, by volume. Even if the average labor intensity of exports was three times that of domestically oriented production, exports would have accounted for less than $10 \%$ of the total labor input in textiles.

Our analysis of employment shall calculate for various periods the equivalent number of full time job equivalents (FTJEs) involved in production. It is clear that spinning has more frequently been a part time activity, and we shall separate spinning from weaving later on, but, in our opinion, treatment of the full employment impact of textiles should incorporate both groups. We can utilize data presented in Prakesh (1974) to estimate that the total employment in 1790 was between 400,000 and 500,000 FTJEs. ${ }^{17}$ The reader will recall that, on the basis of the discussion

15 This supports Ryan's (1981) criticism of Nugent (1973) that it was factors other than the rupee devaluation which spurred, in this case, exports of Indian yarn.

${ }^{16}$ The per capita consumption figure is that of 1850 , which is, as noted, somewhat smaller than our estimates for 1880 and afterward. The main defense of this assumption is convenience; it would have to be two or three times larger for exports to have been significant in overall production, and this is clearly unrealistic.

${ }^{17}$ Using data from a variety of sources, Prakesh estimated that the production (for 
TABLE 6

Prices in India, $1850-1930(1873=100)$

\begin{tabular}{lrrrc}
\hline Year & CPI & Yarn & Cloth & Raw cotton \\
\hline 1850 & 75 & & $(89)$ & $(48)$ \\
1862 & 93 & & $(133)$ & $(82)$ \\
1873 & 100 & 100 & 100 & 100 \\
$1879-1881$ & 105 & 80 & 79 & 90 \\
$1889-1891$ & 111 & 74 & 77 & 91 \\
$1899-1901$ & 124 & 61 & 78 & 77 \\
$1909-1911$ & 144 & 88 & 94 & 119 \\
$1919-1921$ & 326 & 251 & 286 & 201 \\
$1929-1931$ & 199 & 110 & 139 & 110 \\
\hline
\end{tabular}

Sources. CPI data from Singh (1965, p. 685), 1850 data is source's statistic for 1857. Yarn, cloth, and raw cotton prices for 1873 and afterward from Indian Statistical Abstract, various years, representing rupee prices of standard types of exported yarn and imported cloth. Earlier cloth prices from Sandberg (1974, p. 24). Earlier raw cotton prices calculated from data in Mann (1968, pp. 130 and 132), Harnetty (1972, p. 56), and the Indian Statistical Abstract, which gives only values. This may overstate the increase in prices. According to Ellison (1968, Table 1), the price of "Dhol. Fair" rose only $16 \%$ between 1850 and 1873, and it is difficult-but not impossible-to attribute the resultant differential to a lowering of transport costs.

relating to Tables 3 and 4 , we estimate the decline between 1790 and 1830 of "real" exports, and hence of export related employment, at twothirds of the total, let us say 300,000 FTJEs, or about $0.2 \%$ of the population. This drop was not evenly distributed in the economy, however. The data in Table 3 show that the value of Calcutta's exports fell from 14 to 1 million rupees, or by $95 \%$, while that of the rest of the subcontinent declined from 11 to 8 million rupees, or by only $30 \%$. Applying these ratios to the total employment drop yields a decline in Bengal of $244,000{ }^{18}$ and for the rest of India a drop of 56,000 FTJEs. Bengal's exports of silk textiles did increase, but might have absorbed only 10,000 weavers, and few others, as silk preparation is much less labor intensive than cotton. Referring to the data in Table 1, we estimate that the increase in imported yarn might have given employment to 20,000 weavers (and, of course, to no spinners). ${ }^{19}$

export) of 577,690 pieces, equivalent to 9.6 million square yards, would have involved between 75,620 and 99,804 FTJEs, as follows: $5-6$ workers per loom (including 1.5-2 weavers), and an annual production per loom of 36 pieces, totaling 640 square yards per year, at 17 square yards per piece. This works out to around 125 yards per person per year, or 8 FTJE per 1000 yards. Morris's reading of the productivity data in Morris, et al. (1969, p. 128) together with Robson's $(1957$, p. 1) export figure imply a total employment of 550,000 FTJEs.

${ }^{18}$ This is much lower than Sinha's (1970, p. 8) figure of one million in Bengal alone.

${ }^{19}$ This is not as positive a picture as that described by Kumar (1972, pp. 76-77), and weakens one of the bases of Morris's argument cited earlier. 
These calculations highlight the regional impact of the decline in Indian textile exports. For the country as a whole, the drop was certainly significant-perhaps totaling two-thirds-but not a large fraction of the total production. ${ }^{20}$ Exports from the Bengal presidency and to Great Britain were the two parts of the trade that were hardest hit. As Bengal was the seat of the East India Company and British rule, it is natural that reports originating there effectively exaggerated the overall impact on the country. An example is the phrase originally appearing in the British Governor General's report of 1834-1835, and later made famous by Marx, "the bones of the cotton weavers are bleaching the plains of India." 21 In addition to its reflection of a regional bias, the observation effectively ignores the fact that weavers were but a third of those involved in handicraft production, and that they did have some limited access to alternative employment, weaving silk and imported cotton yarn. That English commentators most frequently referred to the lot of weavers, not spinners or other textile workers, reflects the fact that they had greater contact with weavers, who in turn subcontracted with spinners and others. We should not forget that even before 1770 foreigners had often commented on the poverty-stricken lot of weavers, for which neither foreign competition nor famine can be blamed. ${ }^{22}$

As noted above, imports of cloth amounted to about 1 yard per person by 1850 , which might have been $10 \%$ of Indian production. We now turn to the post-1850 period, when Indian production fell to less than $40 \%$ of Indian consumption, the rest being supplied by Lancashire.

Facile discussion of the "de-industrialization of India" can too easily overlook the fact that India ranked fourth worldwide in mill consumption of cotton in 1913 (behind the U.K., U.S. and Germany). ${ }^{23}$ Moreover, mechanized production of yarn and cloth both grew by larger amounts than their corresponding imported totals after 1880 . Therefore, any significant "de-industrialization" solely attributable to British exports would have occurred before that date. So we shall concentrate on the years 1850-1880, when cloth imports increased by 1500 million yards, or 6 yards per person, compared to our estimated total consumption of about 11 yards per capita.

The data presented earlier permit the calculation of the degree to which these imports replaced handicraft production, as contrasted to merely supplying expanding demand due to income and population growth, as

${ }^{20}$ Contrast Sanderson (1951, p. 146): "[by 1850] this entire Indian export of cotton goods has been destroyed by the tariff policies of the British government," which is incorrect both in magnitude and causality.

${ }^{21}$ See the discussion in Sandberg (1974, p. 166) and Morris et al. $(1969$, p. 165 , ftn. 152). Feuerwerker (1970, p. 338) offers a similar quotation from Marx regarding China.

${ }^{22}$ See Chaudhuri (1978, p. 268). The decline of the Mughal empire should also account for a previous drop of specialty weaving, see Ghosal (1966, p. 21).

${ }^{23}$ Robson (1957, p. 19). Because of the pervasiveness of handweaving the ranking in terms of machine made cloth might have been lower. 
was suggested by Morris. The basic procedure is to estimate total consumption in 1850 , from which artisan production is derived by subtracting imports. This involves assuming imported and handicraft textiles are comparable on a volume basis (weight or length), but is incapable of distinguishing between shifts of and movements along a hypothetical supply curve for handicrafts. Such an analysis would involve consideration of changing opportunity costs of handicraft activities, lowered transportation costs, and a model much too detailed for the available data. ${ }^{24}$

One early econometric work on the demand for Indian textiles is the article by Desai (1971), whose import demand functions exhibited high price elasticities. Unfortunately, only one of those equations used a proxy for income, and domestic prices of imports were not deflated by an overall price index. Using somewhat different time series than Desai's, ${ }^{25}$ and including those two variables, we present in Table 7 demand functions for both imports and consumption. The first two equations suggest that Desai's results are replicated for our sample. Inclusion of income and relative prices in Eqs. (3) and (4) lowers the price elasticity considerably. Table 5 presented estimates of total Indian cotton textile consumption for the period 1880-1930. When combined with the price and income data used in Eqs. (1)-(4), this series yields Eq. (5) in Table 7, which can be projected back in time to yield an estimate of total Indian consumption in 1850 of 2130 million, yards, or 9 yards per capita. Our estimates of post-1800 production and consumption are shown in Fig. 1.

For the conversion of cloth production to employment figures, we shall use the 20th-century data cited by Prakesh (1974); a fulltime weaver would produce 1000 square yards per year, and need two or three spinners to produce the yarn, or approximately 3.5 FTJE/1000 linear yards of cloth. ${ }^{26}$ On the basis of the calculations in Table $8,{ }^{27}$ this suggests an

${ }^{24}$ One important factor causing a shift would be the changing relative price of raw cotton and cloth, as shown in Table 6, which, ceteris paribus, would shift handicraft supply to the left. Lacking Indian handicraft production data, we cannot pursue this. For a discussion of studies applied to the United States and the world market which touch on these issues, see Rostow (1975, pp. 740-745).

${ }^{25}$ Price data from the Indian Statistical Abstract, after 1873. Earlier data on the CPI from Singh $(1965$, p. 685$)$ and, for cloth, Sandberg's series of prices in England (1974, p. 249). The per capita income estimates are M. Mukerii's, reported in Singh (1965, p. 689).

${ }^{26}$ Prakesh (1974), footnoes 35-37. In aggregate, these coefficients are comparable to those used for China by Feuerwerker (1970). Also, one report claimed that the productivity in the pre-industrial England of 1720 was 140 yards per person, Wadsworth and Mann $(1931, \mathrm{p}, 120)$. The high ratio of spinners to weavers may indicate the etymological origin of the word spinster. Comparison with our data in footnote 17 shows that we are implicitly treating post-1850 handicraft production as half as labor intensive as earlier production for exports. Furthermore, we are ignoring late 19th century improvements in weaving as being of secondary order of magnitude compared to our other approximations.

${ }^{27}$ The reader will notice that the calculations in Table 8 for 1850 ignore the employment effects of exported handicraft cloth, which cannot have been significant compared to the totals. 
TABLE 7

Regression Results ${ }^{a}$

\begin{tabular}{|c|c|c|c|}
\hline & & $R^{2}$ & Period \\
\hline (1) & $\begin{aligned} \text { Imports }= & 23.0-3.71 \text { Pcloth } \\
& (17.0)(12.9)\end{aligned}$ & 0.67 & $1815-1913$ \\
\hline (2) & Imports $=\begin{array}{c}-12.5-0.69 \text { Pcloth } \\
(3.78)\end{array}$ & 0.90 & $1857-1900$ \\
\hline (3) & $\begin{aligned} \text { Imports }= & 9.27-1.22 \text { Pcloth } / \mathrm{CPI} \\
& (49.7)(11.7)\end{aligned}$ & 0.77 & $1857-1900$ \\
\hline (4) & Imports $=-13.21-0.62$ Pcloth $/$ CPI +1.98 Income & 0.92 & $1857-1900$ \\
\hline (5) & $\begin{array}{c}\text { Consumption }=-0.19-0.30 \text { Pcloth } / \mathrm{CPI}+0.80 \text { Income } \\
(0.15) \quad(2.79)\end{array}$ & 0.54 & $1880-1930$ \\
\hline
\end{tabular}

${ }^{a}$ All variables in logarithms. $t$ Statistics in parentheses. Pcloth, price of cloth; CPI, average price level in India. For sources, see text.

absolute fall in Indian textile employment for 1850 to 1880 of 3.6 million FTJEs, or almost $1 \frac{1}{2} \%$ of the 1850 population of 250 million. ${ }^{28}$ This estimate is subject to many errors, particularly the estimate of hand spun yarn in Table 5, the assumed growth of population and per capita income, and the coefficient relating cloth production to FTJEs, so that a range of 2 to 6 million FTJEs might be more realistic. ${ }^{29}$ Some preliminary reestimates of Eq. (5) indicated that the calculated change in cloth consumption over the $1850-1880$ period was not overly sensitive to increases of even $200 \%$ in estimated hand spinning in 1880 , due to its small part of total consumption in 1880 , as well as the resultant change in the income elasticity in Eq. (5). Similarly, our productivity data are rather crude, and potentially capable of considerable refinement with a more thorough search of the relevent specialized literature.

We have identified as distinct phases of Indian textile history the period of the decline of the export market, the decline of handicraft production, and the rise of domestic industry. Some employment effects of the first two phases have been estimated. Now we shall turn to the broader issue

${ }^{28}$ This is twice the absolute number estimated by Feuerwerker (1970) as the employment loss in China due to imports during 1870 to 1910 . As a fraction of the total population, the difference would be four times larger. Ironically, China's foreign competition was not British piece goods but yarn from India and, later, Japan.

${ }^{29}$ Unpublished results generously made available to the author by Alan Heston suggest a smaller, though still positive, growth of per capita income during the period 1868-1882/ 1883. For a given hypothesized growth of population, the assumption of a smaller increase of per capita income over 1850 to 1880 would raise the estimated level of consumption (and hence production) in 1850, leading to an increase in our estimated FTJE loss due to imports. 
A

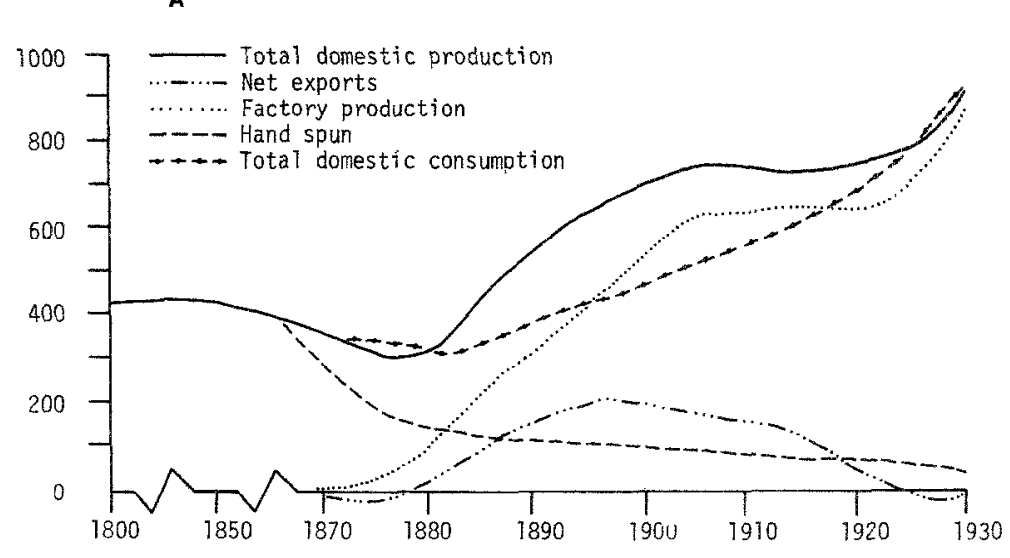

B

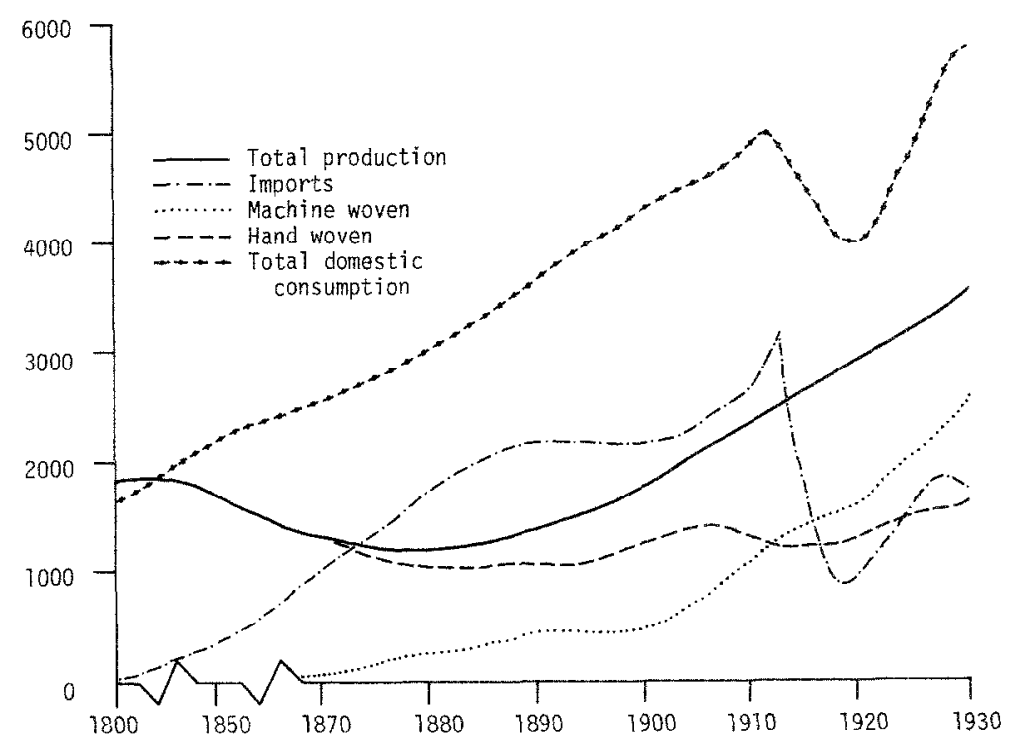

FIg. 1. Cotton goods in India, 1800-1930. (A) Yarn, million pounds; (B) cloth, million yards. The two graphs are constructed on the same scale: $4 \mathrm{yd}$ of cloth $=1 \mathrm{lb}$ of yam.

as raised by Morris; that of an absolute decline in handicrafts (and/or hand weaving) over the whole century. Judgments on this matter depend heavily on the population data utilized, about which estimates show even more variance than those of per capita income levels. Morris's basic point about the importance of population growth counteracting the decline of the export market is clearly justified by our calculations in Table 9 , for the period 1800-1850. In the second half of the century, however, the main factor sustaining hand weaving was the growth of the country's 
TABLE 8

Cotton Textile Handicraft Employment, 1850, 1880

1850 Estimated consumption

- cloth imports

Estimated production - cloth equivalent of imported yarn

Handicraft production of cloth from hand spun yarn

$$
\begin{aligned}
& 2,100 \mathrm{~m} . \mathrm{yd} \\
& \frac{-300}{1,800} \mathrm{~m} . \mathrm{yd} \\
& -100 \mathrm{~m} . \mathrm{yd}
\end{aligned}
$$

$1,700 \mathrm{~m} . \mathrm{yd}$

Estimated employment, @ 3.5 FTJE/1000 yd (hand spun)

Estimated cmploymcnt, @1.0 FTJE/1000 yd (machine spun)

Total estimated employment, 1850

$=5,950,000$ FTJEs

$=\frac{+100,000}{6,050,000}$

$=\overline{6,050,000}$

1880 Estimated hand woven from hand spun yarn $600 \mathrm{~m}$. yd

Estimated hand woven from machine spun yarn $400 \mathrm{~m}$. yd

Estimated employment, @ 3.5 FTJE/1000 yd (hand spun)

Estimated employment, @1.0 FTJE/1000 yd (machine spun)

Total estimated employment, 1880

$=2,100,000$ FTJEs

$=\frac{+400,000}{2,500,000}$

Estimated decline, 1850-1880 3,550,000 FTJEs

TABLE 9

Summary Estimates of Indian Handicraft Textile Employment, 1800-1929

\begin{tabular}{lcccccc}
\hline & $\begin{array}{c}\text { Using hand spun } \\
\text { yarn }\end{array}$ & & $\begin{array}{c}\text { Using machine } \\
\text { spun yarn }\end{array}$ & & \multicolumn{2}{c}{$\begin{array}{c}\text { Weavers } \\
\text { Total } \\
\text { (million FTJEs) } \\
\text { only }\end{array}$} \\
\hline 1800 High estimate & $1810 \times 3.5$ & + & 0 & $=$ & 6.3 & \\
& $1810 \times 1.0$ & + & 0 & $=$ & & 1.8 \\
\multirow{2}{*}{ Low estimate } & $1090 \times 3.5$ & + & 0 & $=$ & 3.9 & \\
1850 & $1090 \times 1.0$ & + & 0 & $=$ & & 1.1 \\
1880 & $1700 \times 3.5$ & + & $100 \times 1.0$ & $=$ & 6.0 & \\
& $1700 \times 1.0$ & + & $100 \times 1.0$ & & & 1.8 \\
1913 & $600 \times 3.5$ & + & $400 \times 1.0$ & $=$ & 2.5 & \\
1929 & $600 \times 1.0$ & + & $400 \times 1.0$ & $=$ & & 1.0 \\
& $360 \times 3.5$ & + & $1140 \times 1.0$ & $=$ & 2.4 & \\
& $360 \times 1.0$ & + & $1140 \times 1.0$ & & & 1.5 \\
& $240 \times 3.5$ & + & $1480 \times 1.0$ & $=$ & 2.3 & \\
& $240 \times 1.0$ & + & $1480 \times 1.0$ & $=$ & & 1.7 \\
\hline
\end{tabular}

Note. The estimates for 1800 assume population are 190 and 110 million, respectively, a per capita cloth consumption of $9 \mathrm{yd}$, and that exported cloth is twice as labor intensive as ordinary cloth. 1800 exports from Robson $(1957$, p. 1). 1850 and 1880 production totals from Table 6; 1913 and 1929 totals from Table 5.

The calculations convert cloth quantities to estimated employment on the basis of 3.5 FTJE/1000 yd (total), and 1.0 FTJE/1000 yd (weavers). 
spinning mills, ${ }^{3 n}$ and hand spinning itself probably declined considerably. Our conclusion is that total handicraft textile employment fell absolutely over the entire century, and that weaving declined down to 1880 . Whether it is more appropriate to look at total handicraft activity or only weaving, and whether the kind of hand weaving that grew up with the mills should be compared with the "traditional" activity are two questions that our analysis is not designed to answer.

This paper has only treated one aspect of the de-industrialization debate. A recent summary of the many issues under discussion is Robb (1981). A fuller evaluation of the quantitative arguments presented here would need an appreciation of the alternatives available to displaced handicraft workers, on which much work still needs to be done. ${ }^{31}$

\section{REFERENCES}

Arasaratnam, S. (1980), "Merchants and the Company: The Handloom Industry in Southeastern India 1750-1790." Indian Economic and Social History Review 17, 257-282.

Bagchi, A. K. (1976), "De-industrialization in India in the Nineteenth Century: Some Theoretical Implications." Journal of Development Studies 17, 135-164.

Baran, P. A. (1957), The Political Economy of Growth, New York: Monthly Review Press. Chao, K. (1977), The Development of Cotton Textile Production in China, Cambridge, Mass.: Harvard Univ. Press.

Chaudhuri, K. N. (1966), "India's Foreign Trade and The Cessation of the East India Company's Trading Activities, 1828-40." Economic History Review 19, 344-363.

Chaudhuri, K. N. (1968), "India's International Economy in the Nineteenth Century: An Historical Survey." Modern Asian Studies 2, 31-50.

Chaudhuri, K. N. (1971), The Economic Development of India Under the East India Company, 1874-58, Cambridge: Cambridge Univ. Press.

Chaudhuri, K. N. (1974), "The Structure of Indian Textile Industry in the Seventeenth and Eighteenth Centuries." Indian Economic and Social History Review 11, 127-182.

Chaudhuri, K. N. (1978), The Trading World of Asia and the English East India Company 1660-1760, Cambridge: Cambridge Univ. Press.

Davis, R. (1979), The Industrial Revolution and British Overseas Trade, Atlantic Highlands, N.J.: Humanities Press.

Deane, P., and Cole, W. A. (1967), British Economic Growth, Cambridge: The University Press. 2nd ed.

Desai, M. (1971), "Demand for Cotton Textiles in Nineteenth Century India." Indian Economic and Social History Review 10, 337-361.

Desai, R. C. (1953), Standard of Living in India and Pakistan 1931-32 to 1940-41, Bombay: Popular Book Depot.

Dewey, C. (1978), "The End of the Imperialism of Free Trade: The Eclipse of the Lancashire Lobby and the Concession of Fiscal Autonomy to India." In C. Dewey and A. G.

${ }^{30}$ Once again, we would hypothesize that transport costs inhibited a pre-1870 growth of Indian handweaving using imported yarn, just as transport costs and tariffs helped protect English spinners from imported Indian yarn before the mid-18th century spurt of inventions.

${ }^{31}$ See, e.g., the July 1975 issue of Explorations in Economic History. According to official statistics, the employment in Indian textile mills was only 44,000 in 1880 , and 350,000 in 1930. The early 19th century experience of Bengal is treated by Ghosal (1966). For a discussion of some other Asian countries, see Resnick (1970). 
Hopkins (Eds.), The Imperial Impact: Studies in the Economic History of Africa and India. Atlantic Heights, N.J.: Humanities Press.

Dutt, R. (1956), The Economic History of India in the Victorian Age, London: Routledge \& Kegan Paul. 8th Impression.

Ellison, T. (1968), The Cotton Trade of Great Britain, New York: A. M. Kelly. New impression of 1886 edition.

Farnie, D. A. (1979), The English Cotton Industry and the World Market, 1815-1896, Oxford: Oxford Univ. (Clarendon) Press.

Feuerwerker, A. (1970), "Handicraft and Manufactured Cotton Textiles in China, 18711910." Journal of Economic History 30, 368-378.

Gadgil, D. R. (1971), The Industrial Revolution of India in Recent Times, 1860-1939, Bombay: Oxford Univ. Press. 5th ed.

Gandhi, M. P. (1930), The Indian Cotton Textile Industry, Calcutta.

Ganguli, B. N. (1977), Indian Economic Thought, Nineteenth Century Perspectives, New Delhi: Tata McGraw-IIill.

Ghosal, H. R. (1966), Economic Transition of the Bengal Presidency, Calcutta: Firma K. L. Mukhopadhyay.

Govil, K. L. (1950), The Cotton Industry of India, Bombay: Hind Kitabs. 2nd ed.

Hanson, J. R. (1979), "World Demand for Cotton during the Nineteenth Century: Wright's Estimates Re-examined," Journal of Economic History 39, 1015-1021.

Harnetty, P. (1972), Imperialism and Free Trade, Lancaster and India in the Mid-Nineteenth Century, Manchester: The University Press.

Heston, A. (1973), "Official yields per Acre in India 1886-1947." Indian Economic and Social History Review 11, 303-332.

Hunter, W. W. (1886), The Imperial Gazetteer of India, London: Trubner. Vol. VI.

Imlah, A. H. (1958), Economic Elements in the Pax Britannica, New York: Russell and Russell.

(India) (1927), Report of the Indian Tariff Board, Bombay: Government Central Press.

Institut International D'Agriculture, International Yearbook of Agriculture Statistics, various years, Rome.

Kumar, D. (1972), "Economic History of Modern India," Indian Economic and Social History Review 11, 63-90.

MacGregor, J. (1850), Commerical Statistics, London: Whitaker. Vol. IV, 2nd ed.

Maddison, A. (1971), Class Structure and Economic Growth. India and Pakistan Since the Moghuls. New York: Norton.

Mann, J. (1968), The Cotton Trade of Great Britain, London: Frank Cass. Reprint of 1860 edition.

McAlpin, M. B. (1975), "Railroads, Prices and Peasant Rationality: India 1860-1900." Journal of Economic History 34, 662-684.

McEvedy, C., and Jones, R. (1978), Atlas of World Population History, New York: Facts on File.

Mehta, S. D. (1953), The Indian Cotton Textile Industry: An Economic Analysis, Bombay: G. K. Ved.

Mehta, S. D. (1954), The Cotton Mills of India 1854 to 1954, Bombay: G. K. Ved.

Milburn, W. (1813), Oriental Commerce ..., London: Black, Parry.

Mitra, D. B. (1978), The Cotton Weavers of Bengal, Calcutta: Temple Press,

Morris, M. D. (1963), "Towards a Re-interpretation of Nineteenth Century Indian Economic History," Journal of Economic History 23, 606-618.

Morris, M. D., et al. (1969), Indian Economy in the Nineteenth Century: A Symposium. Delhi: Hindustan Publ.

Morris, M. D. (1974), "The Population of All India 1800-1951." Indian Economic and Social History Review 11, 309-313. 
Nugent, J. B. (1973), "Exchange Rate Movements and Economic Development in the Late Nineteenth Century," Journal of Political Economy 81, 1110-1135.

Ohkawa, K., et al. (Ed.) (1966), Estimates of Long Term Economic Statistics of Japan Since 1868. Vol. 9. Agriculture and Forestry, Tokyo: Toyo Keizai Shinposha.

Parshad, I. D. (1932), Some Aspects of Indian Foreign Trade, 1757-1893, London: P. S. King.

Pearse, A. S. (1930), The Cotton Industry of India, London: Taylor Garnett Evans.

Prakesh, O. (1974), "Bullion for Goods: International Trade and the Economy of Early Eighteenth Century Bengal." Indian Economic and Social History Review 13, 159187.

Resnick, S. A. (1970), "The Decline of Rural Industry Under Export Expansion: A Comparison Among Burma, Phillipines and Thailand, 1870-1938," Journal of Economic History 30, $51-73$.

Rider, T. D. (1970), "Tariff Policy of the Government of India and Industrial Development 1894-1934." Journal of Economic History 30, 278-280.

Robb, P. (1981), "British Rule and Indian 'Improvement'." Economic History Review 34, 507-523.

Robson, R. (1957), The Cotton Industry in Britain, London: Macmillan.

Rostow, W. W. (1975), How it all Began, the Origins of the Modern Economy, New York: McGraw-Hill.

Ryan, J. S. (1981), "Silver and the Indian Economy, 1870-1892." Paper presented at the 22nd Annual Cliometrics conference.

Sandberg, L. G. (1974), Lancashire in Decline, Columbus: Ohio State Univ. Press.

Sanderson, G. D. (1951), India and British Imperialism, New York: Bookman.

Seki, K. (1956), The Cotton Industry of Japan, Tokyo: Japanese Society for the Promotion of Science.

Singh, V. B. (Ed.) (1965), The Economic History of India, 1857-1956, Bombay: Allied Publ.

Sinha, N. K. (1970), The Economic History of Bengal, 1793-1848, Calcutta: Firma K. L. Mukhopadhyay. Vol. III.

Thorner, D. (1962), Land and Labour in India, Bombay: Asia Publ. House.

Tripathi, A. (1956), Trade and Finance in the Bengal Presidency, 1793-1833, Bombay: Orient Longmans.

Utley, F. (1931), Lancashire and the Far East, London: Allen and Unwin.

Vicziany, M. (1979), "The Deindustrialization of India in the Nineteenth Century: A Methodological Critique of Amiya Kumar Bagchi." Indian Economic and Social History Review 14, 105-147.

Wadsworth, A. P., and Mann, J. (1931), The Cotton Trade and Industrial Lancashire 16001780, Manchester: Manchester Univ. Press.

Wright, G. (1974), "Cotton Competition and the Post-Bellun Recovery of the Anerican South." Journal of Economic History 34, 610-635. 